\title{
Kemampuan Negosiasi Pengusaha dalam Meningkatkan Kesepakatan Bisnis
}

\author{
YUSUF HAMDAN ${ }^{1}$, ANNE RATNASARI ${ }^{2}$, AZIZ T. HIRZI ${ }^{3}$ \\ 1,2,3 Fakultas Ilmu Komunikasi Unisba, Jl. Tamansari No. 1 Bandung \\ Email :1'yusuf.hamdan@gmail.com,2anneratnasari10@gmail.com,3azizhirzi@yahoo.com
}

\begin{abstract}
Entrepreneurs as a business negotiator, in order to successfully improve the deal with his business partner needs to be supported by a variety of aspects. One of them through negotiation capability. This study aims to determine the ability of employers' views on aspects of the negotiations digging courage, patience persists, ask for more courage, integrity, and their activities as a listener when negotiating. This research method qualitative single case study. Data collected by observation, interview, and literature. The informants were women entrepreneurs officers and members of Ikatan Wanita pengusaha Indonesia (IWAPI) West Java. The findings of this study, women entrepreneurs were able to dig up information, is able to give a sense of comfort to the other party during negotiations, have the patience to last longer than the other negotiator to provide timely and positive thinking, dare to ask for more focus on the purpose and process sequence achievement, integrity presses win-win solutions through commitment and attention to the common interest, capable of being a good listener through providing discussion time and as empathetic listener.
\end{abstract}

Keyword: businesswoman, negotiation, business

\begin{abstract}
Abstrak. Pengusaha sebagai negosiator bisnis supaya berhasil meningkatkan kesepakatan dengan mitra bisnisnya perlu didukung oleh berbagai aspek. Salah satunya melalui kemampuan negosiasi. Penelitian ini bertujuan mengetahui kemampuan negosiasi pengusaha dilihat pada aspek keberanian menggali informasi, kesabaran bertahan, keberanian meminta lebih banyak, integritas, dan aktivitas mereka sebagai pendengar saat negosiasi. Metode penelitian ini kualitatif dengan studi kasus tunggal. Pengumpulan data dilakukan dengan observasi, wawancara, dan kepustakaan. Informan penelitian adalah wanita pengusaha pengurus dan anggota Ikatan Wanita pengusaha Indonesia (IWAPI) Jawa Barat. Temuan penelitian ini, wanita pengusaha mampu menggali informasi, mampu memberi rasa nyaman kepada pihak lain saat negosiasi, memiliki kesabaran bertahan lebih lama dari negosiator lain dengan menyediakan waktu dan berpikir positif, berani meminta lebih banyak fokus pada tujuan dan urutan proses pencapaiannya, memiliki integritas menekan solusi menang-menang melalui komitmen dan memerhatikan kepentingan bersama, mampu menjadi pendengar yang baik melalui menyediakan waktu diskusi dan sebagai pendengar empatik.
\end{abstract}

Kata kunci: wanita pengusaha, negosiasi, bisnis

\section{Pendahuluan}

Wanita pengusaha memiliki peran strategis dalam memajukan perekonomian masyarakat, karena diketahui usaha mereka dapat memberdayakan individu untuk berkreasi menghasilkan karya terbaik.

Kesuksesan bisnis mereka mendapat dukungan berbagai pihak terkait, yang memberi peluang agar usaha mereka berkembang maju. Bila keterampilan mengelola bisnis meningkat, usaha mereka diharapkan akan memberikan profit. Aktivitas wanita pengusaha, khususnya yang tergabung dalam Ikatan Wanita pengusaha Indonesia (IWAPI) Jawa Barat, menurut Euis Atikah, sebagai ketuanya, antara lain, "dapat mengurangi pengangguran, dan memberikan pemasukan untuk pemerintah daerah. Aspek lain yang membanggakan, yaitu produk-

Received: 25 September 2014, Revision: 28 Mei 2015, Accepted: 16 Juni 2015

Print ISSN: 0215-8175; Online ISSN: 2303-2499. Copyright@2015. Published by Pusat Penerbitan Universitas (P2U) LPPM Unisba

Terakreditasi SK Kemendikbud, No.040/P/2014, berlaku 18-02-2014 s.d 18-02-2019 
produk usaha yang dikelola wanita pengusaha bisa menembus pasar ekspor" (pikiranrakyat.com.,08 Februari 2011).

Beberapa program yang dikembangkan IWAPI, di antaranya, peningkatan kualitas sumberdaya manusia, perluasan pasar, dan membuka akses modal (teraskreasi.com, 6 Juni 2014). Di sisi lain, agar wanita pengusaha menjadi pengusaha sukses, (dalam koransindo.com, 6 Juni 2014), "Wanita pengusaha bukan hanya menghasilkan produk yang berkualitas, tetapi juga fokus kuantitas produksi. Faktor lain yang juga penting adalah bergaul dengan lingkungan yang tepat. Sedangkan untuk memenangkan persaingan, pengusaha harus fokus pada kecepatan, karena saat ini telah memasuki persaingan bebas dan Asean Economi Community (AEC) 2015."

Menteri Koperasi dan Usaha Kecil Menengah (UKM), Syarief Hasan, menuturkan, Ikatan Wanita pengusaha Indonesia (IWAPI) ikut berperan dengan menciptakan lahirnya pengusaha-pengusah baru yang tangguh dan berdaya saing (suaramerdeka.com., 6 Juni 2014). Berbagai jenis usaha dikembangkan oleh wanita pengusaha di Jawa Barat, di antaranya bidang produk seperti fashion, kuliner, perhiasan, kerajinan, atau di bidang jasa, misalnya pengelola travel, salon, transportasi, dan lainnya (swa.co.id, 6 Juni 2014). Saat ini, dari seluruh anggota IWAPI sebanyak $85 \%$ adalah yang bergerak di skala mikro dan kecil, $13 \%$ merupakan pengusaha skala menengah, dan $2 \%$ pengusaha besar (iwapijawabawat.com, 23 Maret 2012).

Wanita pengusaha dalam menjalankan bisnisnya tidak selalu dalam kondisi yang mendukung. Salah satu hambatan yang terjadi adalah "kesadaran wanita pengusaha untuk proaktif mengembangkan usaha perlu ditingkatkan" (pikiran-rakyat. com., 08 Februari 2011). Hal ini berarti, wanita pengusaha perlu memiliki keuletan, ketekunan, ketelitian, dan inisiatif untuk berbenah dan mengambil tindakan efektif dan terarah dalam mengembangkan usahanya.

Sejalan dengan program pemerintah menurunkan angka kemiskinan dan pengangguran, mereka diharapkan ikut berperan sebagai pengusaha yang memiliki mental kuat dan berdaya saing. Karena itu wanita pengusaha diharapkan dapat menangkap peluang memasarkan produk dan jasa perusahaan mereka, dan memiliki keterampilan agar menghasilkan penjualan yang menguntungkan. Salah satunya memiliki keterampilan negosiasi bisnis. Keterampilan tersebut diharapkan dapat meningkatkan kemampuan mereka untuk menjadi pelaku usaha yang tangguh, lebih mengedepankan jiwa wirausahanya. Berdasarkan latar belakang masalah tersebut, dapat dirumuskan suatu permasalahan sebagai berikut, "Bagaimana kemampuan negosiasi pengusaha dalam meningkatkan kesepakatan bisnis?"

Fokus kajian artikel ini adalah pada bagaimana kemampuan pengusaha ketika bernegosiasi, khususnya dalam menggali informasi secara terus-menerus, keberanian meminta konsesi, kesabaran untuk bertahan, kesediaan menjadi pendengar yang baik yang dilakukan wanita pengusaha agar meningkatkan kesepakatan bisnis. Pendekatan penelitian menggunakan pendekatan kualitatif dengan studi kasus tunggal (lihat Yin, 2002:18). Pengumpulan data dilakukan dengan observasi, wawancara, dan studi pustaka.

\section{Kemampuan Negosiasi Pengusaha}

Memasarkan produk dan jasa merupakan salah satu kegiatan komunikasi pemasaran, masuk pada penjualan pribadi (personal selling), yaitu presentasi lisan berbentuk percakapan di hadapan satu atau beberapa calon pembeli dengan maksud untuk menjual. Penjualan pribadi menggunakan saluran komunikasi antarpribadi dan berlangsung dalam jaringan pergaulan antarmanusia. Penjualan pribadi ini memerlukan pengetahuan dan keterampilan negosiasi, karena bentuk kegiatannya paling interaktif dan digunakan untuk memertahankan hubungan jangka panjang (Kotler, 2000: 87; Shimp, 2014: 5-6).

Komunikasi berperan penting dalam proses negosiasi. Miller (dalam Mulyana, 2000: 54) menjelaskan komunikasi adalah "situasi yang memungkinkan suatu sumber mentransmisikan suatu pesan kepada seorang penerima dengan disadari untuk memengaruhi perilaku penerima." Pada bidang bisnis, pihak-pihak yang bernegosiasi merupakan komunikator yang aktif mengomunikasikan gagasan tentang alternatif yang mungkin disepakati bersama (Sujana, 2004:13). Proses komunikasi yang terjadi termasuk ke dalam konteks komunikasi antarpribadi dan komunikasi kelompok kecil.

Komunikasi antarpribadi, yaitu interaksi verbal dan nonverbal antara dua (atau kadang-kadang lebih dari dua) orang yang saling bergantung (DeVito, 2013:5). Julia T. 
Wood (2013:38), menjelaskan komunikasi antarpribadi adalah "Suatu proses selektif, sistematis, dan terus menerus, dimana individu berinteraksi untuk merefleksikan dan membangun pengetahuan personal dan maknanya, dan prosesnya adalah transaksional, karena proses pengiriman dan penerimaan pesan terjadi pada waktu yang bersamaan. Komunikasi antarpribadi melibatkan dua orang yang mempunyai pendapat, sikap, dan perilaku yang berbeda. Komunikasi ini juga menuntut adanya pertukaran informasi di antara para pelaku yang terlibat dalam komunikasi."

Komponen komunikasi antarpribadi tatap muka saling berkaitan satu sama lain. Oleh karena itu dalam komunikasi antarpribadi adanya sifat saling tergantung dan prosesnya tidak dapat diubah, mempunyai dimensi isi dan hubungan, artinya komunikasi memiliki isi dan hubungan di antara para pelakunya (DeVito, 2013:22).

Dawson (2004: xii) menjelaskan, negosiasi adalah "proses berunding antara dua pihak untuk mencapai kemenangan bersama." Sedangkan proses berunding, menurut Fisher, et al. (2000: 37),

\begin{abstract}
"proses berkomunikasi, saling mendengarkan pendapat untuk mencapai sebuah persetujuan komunikasi." Dalam negosiasi meski terjadi antara dua pihak dengan latar belakang yang sama, memerlukan upaya sungguhsungguh untuk mencapai kesepakatan yang menguntungkan bagi kedua belah pihak.
\end{abstract}

Terdapat dua bentuk kesepakatan yaitu integratif dan distributif. Kesepakatan integratif adalah tawar-menawar untuk mencapai win-win solution (Lewicki, 2003: 113), sedangkan kesepakatan distributif yaitu tawar-menawar untuk keuntungan salah satu pihak (Lewicki, 2003: 74). Negosiasi menggunakan informasi dan kekuatan untuk memengaruhi tingkah laku ke dalam suatu jaringan yang penuh tekanan (Cohen, 2006:4).

Negosiasi bisnis adalah negosiasi yang ditujukan untuk menunjang proses keberhasilan bisnis. Dawson (2004:10) menjelaskan negosiasi bisnis mengajarkan cara mencapai kemenangan di meja negosiasi di mana penjual dan pembeli merasa menang, keterampilan ini merupakan ciri negosiator yang cerdik. Negosiasi bisnis ini ditelaah pada aspek menawarkan produk dan jasa oleh pengusaha yang banyak digunakan pada personal selling (penjualan pribadi), karena pada penjualan pribadi yang memerlukan banyak pengetahuan dan keterampilan negosiasi (Sutisna, 2001: 311). Penjualan pribadi melakukan penjualan langsung sehingga dalam pelaksanaannya terjadi interaksi sosial dan saling pengaruh sehingga negosiasi memiliki peran penting.

Negosiasi yang dilakukan oleh para pengusaha melakukan tawar-menawar yang berlangsung dengan kesediaan saling memberi dan menerima konsesi di antara negosiator. Sedangkan hasil negosiasi yang ingin dicapai, yaitu tercapainya kesepakatan integratif adalah tawar-menawar untuk mencapai win-win solution (Lewicki, 2003: 113). Dengan demikian, kesepakatan bisnis di sini difokuskan pada kesediaan memberi dan menerima konsesi pada wanita pengusaha dengan mitra bisnisnya.

Kemampuan negosiasi pengusaha difokuskan pada kemampuan negosiator dalam mengelola aktivitas negosiasi. Kemampuan negosiator, antara lain, dapat dilihat dari karakteristik personal mencakup keberanian menggali lebih banyak informasi, sabar bertahan lebih lama dari negosiator lawan, berani meminta lebih, integritas menekan untuk solusi menang-menang, dan kesediaan menjadi pendengar yang baik (Dawson, 2004: 351-356).

Keberanian menggali lebih banyak informasi dari seorang negosiator yang baik akan menanyakan informasi dari pihak lawan untuk mengetahui lebih dalam. Negosiator akan menginvestigasi apa pun yang ingin diketahuinya tentang negosiasi yang akan dilaksanakan. Sabar bertahan lebih lama dari negosiator lawan, artinya negosiator adalah orang yang sangat sabar, membuat suatu kesepakatan yang terbaik bagi semua pihak (Dawson, 2004: 352). Keberanian meminta lebih akan membuahkan kesepakatan yang menguntungkan.

Integritas menekan mencapai solusi menang-menang, kesadaran menciptakan solusi menang-menang dapat dilatih dengan mengedepankan kepentingan pihak lain dengan memiliki pikiran jernih, sehingga negosiator memiliki kejujuran demi mencapai solusi mencari keuntungan bersama. Kesediaan menjadi pendengar yang baik dalam negosiasi juga penting. Kemungkinan besar pihak lain akan sepakat dengan negosiator kalau negosiator bersedia mendengarkan tuntutan pihak lawan.

Kesepakatan dalam negosiasi, salah satunya diperoleh dari hubungan baik. 
Membangun hubungan baik di antara negosiator dengan mitra bisnisnya, menurut Budyatna dan Ganiem (2011:156-158) antara lain melalui keramahtamahan, kepercayaan, pengungkapan diri, dan tanggung jawab. Keramahtamahan muncul dari pribadi yang gembira dan menyenangkan. Kepercayaan di mana seseorang menyatakan pikiran, gagasan, ide, kepada orang lain, dan hasilnya menguntungkan bersama. Kepercayaan timbul bilamana terdapat sikap mendukung (supportiveness) (DeVito, 2013:274).

Pengungkapan diri proses di mana seseorang berbagi informasi, sehingga orang lain dapat mengerti. Dalam keadaan tersebut diperlukan empati, yaitu kemampuan seseorang untuk mengetahui apa yang sedang dialami orang lain pada suatu saat tertentu, dari sudut pandang orang lain melalui pandangan orang lain secara verbal, nonverbal, dan melalui kedekatan fisik (DeVito, 2013:248). Tanggung jawab di mana seseorang menyediakan waktu dan energi dalam berkomunikasi, yang menghasilkan kepuasan bersama, terbuka dengan cara bereaksi secara spontan, perasaan dan pikiran yang dilontarkannya adalah milik sendiri dan ia bertanggung jawab. Tanggung jawab ini akan terwujud jika suasananya setara. Kesetaraan adalah suatu keinginan yang secara eksplisit diungkapkan untuk bekerja sama memecahkan masalah tertentu (DeVito, 2013: 299).

Pengumpulan data penelitian ini diperoleh melalui wawancara mendalam kepada wanita pengusaha, baik sebagai pengurus maupun anggota IWAPI. Jenis usaha mereka adalah produk dan jasa. Produk, antara lain, mengenai produk makanan (kue kering), pakaian, bengkel. Sedangkan bidang jasa mencakup jasa travel, salon, dan pakaian.

Kemampuan negosiasi berperan besar dalam meningkatkan kesepakatan bisnis. Kemampuan negosiasi dapat ditelaah dari karakteristik personal negosiator, antara lain terdiri atas: (1) keberanian menggali lebih banyak informasi, (2) kesabaran untuk bertahan lebih lama dari negosiator lawan, (3) berani meminta lebih, (4) integritas menekan solusi menang-menang, dan (5) kesediaan menjadi pendengar yang baik.

\section{Keberanian Menggali Lebih Banyak Informasi}

Keberanian menggali lebih banyak informasi, artinya, negosiator memiliki keberanian terus-menerus menanyakan apa yang mereka ketahui tentang pihak lawan, dan yang lebih penting, menanyakan asumsiasumsi yang telah mereka buat berdasarkan pengetahuan tersebut. Selama mengumpulkan informasi memakai pendekatan investigasi (Dawson, 2004: 351).

Berdasarkan wawancara dengan pengusaha bidang pakaian (menjahit seragam, baju olahraga, dsb.) ditemukan bahwa, informan berusaha menanyakan informasi dari pihak lawan untuk mengetahui lebih mendalam. Dengan cara bertanya, dan bilamana ditemukan ketidakjelasan disusul dengan pertanyaan berikutnya. Informan mengatakan bila bertanya kepada negosiator lain, kegiatan tersebut perlu dilakukan secara hati-hati, karena mempertimbangkan aspek perasaan lawan negosiasinya.

Dengan penjelasan tersebut berarti informan memiliki keberanian menggali lebih banyak informasi. Tujuan lainnya yang ingin dicapai untuk menjaga agar pihak lain merasa nyaman berkomunikasi dengannya". Cara yang dilakukan dengan mengajukan banyak pertanyaan kepada pihak lain, dan memberi kesempatan kepada pihak lain untuk bertanya. Sebagai contoh, informan menanyakan tentang topik apa saja yang akan dibahas pada awal negosiasi, berapa penawaran yang disampaikan, kalau terjadi kesepakatan bekerjasama kapan waktu memulainya, setelah diterima penawaran dari pihak lain, kapan negosiator akan membalas menawarnya, kemudian negosiator juga mempertimbangkan kapan penawaran akhir disampaikan. Dengan demikian, informan dapat memperoleh informasi penting.

Ada juga informan yang menerapkannya dalam menawarkan produk dan jasa, prosesnya sama saja yaitu dengan mengajukan sejumlah pertanyaan guna memastikan kebutuhannya. Misalnya, informasi yang diperoleh berupa data harga dan fasilitas competitor sebagai data pembanding.

Pendapat yang senada dikemukakan Thomas (2007: 167), menggali lebih banyak informasi dengan mengajukan banyak pertanyaan dan berikan kesempatan kepada pihak lain untuk bertanya kepada Anda. Memotong percakapan negosiator lain akan mengganggu kelancaran percakapan itu.

Informan juga menjelaskan, "aktivitas ketika mengajukan pertanyaan dimulai dari berpikir tentang tujuan negosiasi yang ingin dicapai". Apa kemungkinannya, informan juga membuat urutan rangkaian 
proses pencapaian, dan tentu saja dengan mempertimbang untung dan ruginya, baru kemudian ditentukan aspek keuntungan dan kerugiannya. Setelah itu dan yang paling penting, laksanakan sesuai rencana. Dengan mengajukan pertanyaan tersebut memungkinkan negosiator memperoleh informasi penting. Bila hal itu diterapkan dalam memasarkan produk dan jasa, mengajukan pertanyaan dapat dimulai dari analisis kebutuhan. Ziglar (2009:121) mengungkapkan, "Apapun produk atau jasanya, Anda harus menganalisis kebutuhan dari prospek dengan mengajukan sejumlah pertanyaan guna memastikan kebutuhan prospek."

Hal lainnya yang dapat dilakukan informan yang bergerak dalam bidang Meubel dengan, "menelaah kata-kata yang akan diucapkan, yang paling mudah adalah sebelumnya dengan membayangkan dirinya mengucapkan kalimat tersebut dan perkirakan apa dampak yang mungkin terjadi. Jika memang perlu dan tidak akan menimbulkan masalah, kalimat tersebut boleh diucapkan. Jika diperkirakan akan membuat suasana tidak nyaman, informan memilih menunda dulu, atau memilih kata-kata lain yang dimungkinkan lebih cocok."

Informan juga mengatakan bahwa dia menanyakan apa yang menjadi permintaan pihak lain, dan berusaha menggali informasi lebih mendalam atas pernyataan dari pihak lain tersebut. Mereka juga menyadari bahwa keberanian menggali informasi tersebut ditekankan pada sikap mental yang perlu dikembangkan dengan terus latihan. Misalnya, kalau menawar, informan suka mencoba berbagai kemungkinan, misalnya, bagaimana kalau beli dalam jumlah banyak? Tentu ada perbedaan harga dengan membeli dalam jumlah terbatas.

Karakteristik personal negosiator ditinjau dari keberanian menggali lebih banyak informasi, memperlihatkan bahwa informan tersebut memiliki kemampuan sebagai negosiator yang memiliki power, yaitu negosiator yang mampu membuat pihak lawan merasa menang (Dawson, 2004: xii). Negosiator berani bertanya kepada pihak lawan secara terus-menerus demi memastikan apa yang mereka ketahui tentang pihak lawan, misalnya, negosiator menanyakan halhal yang tidak mudah, mungkin pertanyaan tersebut tidak bisa mereka jawab. Negosiator menjadi tahu reaksi mereka atas pertanyaan negosiator. Hal ini melatih negosiator untuk terus mengembangkan diri sebagi negosiator yang memiliki sikap mental positif.

\section{Sabar Bertahan Lebih Lama dari Negosiator Lawan}

Wawancara kepada pengusaha bengkel dan salon mobil, diperoleh informasi menarik, sabar bertahan lebih lama dari negosiator lawan seringkali mendapat banyak hikmah. Sebagai contoh, negosiator lain memberi kesepakatan terbaik, berkat buah dari kesabaran dengan mengatakan, "Kesabaran merupakan hal penting karena pihak lain mengubah pikirannya, perlu waktu untuk menimbang-nimbang berbagai alternatif."

Selanjutnya pengusaha menyebutkan, pernah melakukan penawaran yang membuahkan hasil terbaik, di mana penawaran disampaikan pada satu hari, dan negosiator lain memberikan tanggapan keesokan harinya, untuk memberi waktu kepada pihak lain memikirkannya, dan ia menghubungi lagi besok hari. Pihak lawan mempunyai kesempatan untuk merenungkan semua yang telah terjadi, pengusaha tersebut memiliki keyakinan bahwa kesepakatan yang dibuat secara perlahan menjadi kesepakatan yang hasilnya bagus.

Dengan demikian, negosiasi seringkali diperoleh pihak yang mampu bertahan lebih lama dari negosiator lain, karena untuk negosiasi yang memerlukan tambahan waktu, kesabaran negosiator sangat diuji untuk menghasilkan kesepakatan terbaik. Dawson (2004: 352) mengemukakan, negosiator yang baik adalah orang yang sangat sabar yang tidak akan membiarkan tekanan waktu menggiring mereka sampai membuat suatu kesepakatan yang bukan merupakan kepentingan terbaik bagi setiap pihak. Memerhatikan kenyataan seperti itu, kesabaran negosiator perlu terus dilatih, agar mendapatkan kesepakatan terbaik yang menguntungkan bagi kedua belah pihak.

\section{Keberanian Negosiator Meminta Lebih}

Informan penelitian yang memiliki bisnis kue kering mengatakan, dalam menjalankan bisnisnya pengusaha perlu memiliki keberanian mengemukakan keinginannya kepada pihak lain. Karena orang yang berani meminta lebih banyak kemungkinan akan membuahkan kesepakatan yang menguntungkan.

Keberanian meminta lebih, artinya negosiator menyatakan posisi kemungkinan 
maksimum yang dapat diterima (Dawson, 2004: 353). Dalam kenyataannya, pihak lain tidak begitu saja mau menerima penawaran negosiator, apalagi bila dikaitkan dengan sejumlah faktor pendukung yang perlu disiapkan, misalnya penawaran yang terlalu rendah berimplikasi pada biaya yang akan diterima, atau tidak berani meminta karena takut ditertawakan. Di sinilah kreativitas negosiator diperlukan, bagaimana memecahkan masalah yang menyenangkan bagi kedua belah pihak.

\section{Integritas Menekan untuk Solusi "Menang-Menang"}

Menurut pengusaha konveksi, pengusaha sebagai negosiator perlu memiliki keberanian untuk menekan pihak lain, agar bersedia menciptakan solusi "menangmenang(win win solution)." Karena negosiator yang berorientasi untuk menciptakan solusi menang-menang perlu dikondisikan, agar pihak-pihak yang bernegosiasi sama-sama menang." Artinya, pengusaha memerhatikan kepentingan sendiri, juga kepentingan pihak lain, sehingga sama-sama mencapai win-win solution.

Untuk meningkatkan kesepakatan bisnis dalam negosiasi, salah satu aspek yang penting untuk diperhatikan adalah jujur dan tulus (Dawson, 2004: 354). Karena dalam suatu situasi mungkin ditemukan kesempatan untuk "memancing di air keruh" terhadap pihak lawan yang lemah. Jujur dan tulus seperti yang disampaikan Dawson, ditambah pendapat Santosa (2010:145), yaitu semangat kerja yang tinggi, dan berpikir positif, bilamana sudah menjadi pegangan hidup negosiator, memberi manfat yang besar bagi kemajuan bisnis.

Selain itu, negosiator sebagai insan beragama (Islam), dapat meningkatkan ibadah, salah satunya rajin membaca Al Quran. Subianto (2004: 80) menyebutnya Impossiblity Quotient (ImQ), yaitu suatu strategi untuk memaksimalkan kecerdasan manusia dalam mencapai tujuan. Kecerdasan yang digerakkan oleh hati yang bersih, hasilnya adalah imajinasi yang terus berkembang, mengalir mengikuti kata hati, mencari kebenaran, hingga menemukan kebenaran yang hakiki, yaitu Al-Quran.

Informan penelitian juga telah mengaplikasikan tuntunan agama tersebut dalam bisnisnya. Sebagai contoh, informan mengatakan dalam bisnisnya keuntungan bukan nomor satu, yang nomor satu adalah kejujuran, bagaimana menerapkan amanah, sehingga perusahaan dalam suatu periode mengundang ustadz atau ustadzah untuk ceramah agama, membina akhlak karyawan, dan seluruh jajaran di perusahaan tersebut.

Hal itu menghasilkan kebiasaan yang baik, dan memberi manfaat yang besar bagi perusahaan. Karena pesan moral yang disampaikan serta ajakan untuk selalu berdoa dan tawakal. Contoh, semangat yang kerap didengungkan seperti bekerja adalah ibadah. Bentuk ibadah lainnya yaitu membaca AlQuran dan mengambil hikmah dari ayat-ayat yang dibaca, membersihkan hati, hingga menemukan kebenaran yang hakiki. Di mana dapat menjawab persoalan hidup. Selain itu, juga dapat diterapkan untuk berbisnis, untuk mengatasi persoalan atau menjaga agar bisnis tetap berjalan lancar.

Memiliki integritas untuk mendorong solusi menang-menang merupakan suatu kesempatan yang sangat berharga dan perlu terus dipelihara oleh negosiator, sehingga orang percaya dan merasa nyaman, dan aman bernegosiasi untuk menghasilkan kesepakatan bisnis yang luar biasa.

\section{Kesediaan Menjadi Pendengar yang Baik}

Kesediaan menjadi pendengar yang baik menjadi salah satu syarat terwujudnya kesepakatan di antara para pihak. Pengusaha pupuk mengemukakan pendapatnya,"Pihak lain akan merasa nyaman membuat kesepakatan dengan kita apabila pihak lain yakin negosiator telah memahami apa yang dituntutnya, dengan menempatkan diri pada posisi orang yang mendengar". Dengan demikian, sebagai contoh, upaya yang dilakukan dengan membuat orang lain merasa nyaman dan senang, memperoleh relasi yang banyak.

Dengan demikian, sebagai negosiator perlu mendengar secara aktif, tidak hanya memahami sejauh yang didengar, tetapi juga menunjukkan perhatian atas penjelasan yang disampaikan, memintanya sekali lagi untuk menjabarkan maksudnya dengan lebih jelas. Mendengarkan (listening) merupakan keterampilan yang dapat dipelajari dalam kehidupan. Pada umumnya, orang kurang menjadi pendengar yang baik.

Karena itu, salah satu cara untuk memperbaikinya dengan cara meningkatkan keterampilan mendengarkan. Misalnya, dengan latihan bagaimana memahami dan mengingat perkataan orang lain. 
Memahami adalah unsur ketiga dari proses mendengarkan. Memahami diartikan sebagai proses pemberian makna pada kata yang kita dengar, yang sesuai dengan makna yang dimaksudkan oleh pengirim pesan, sedangkan mengingat adalah menyimpan informasi untuk diperoleh kembali.

Mendengarkan apa yang dikemukakan pihak lawan masuk dalam jenis mendengarkan untuk informasi, yang ditujukan untuk mencari informasi. Sebagai contoh, seorang negosiator yang mendengarkan keinginan pihak lain, dia sedang mendengarkan untuk mendapat informasi.

Berdasarkan temuan penelitian, pengusaha perlu menjadi pendengar empatik, di mana dia mendengarkan pihak lain secara saksama, ikut merasakan masalah yang dihadapi pihak lain. Misalnya, seorang pengusaha kue kering ketika bernegosiasi dengan pemasok (suplier) susu sapi, menjelaskan dirinya mendengarkan secara empatik dengan cara mendengarkan penjelasan suplier susu sapi tersebut dengan memerhatikan arah pembicaraan, bertanya mengenai aspek-aspek yang belum dimengerti, seperti mengapa suplier susu sapi perlu konsesi lebih banyak, apa yang melatarbelakanginya, dan memikirkan bagaimana solusi terbaik bagi keduanya.

Mendengarkan secara empatik yang dilakukan oleh dua pihak yang bernegosiasi tersebut, sesuai dengan pendapat DeVito (2013:95) bahwa mendengarkan dengan empatik apabila seseorang mengerti apa yang dimaksud oleh orang lain dan memahami apa perasaan mereka. Berempati kepada orang lain adalah merasakan apa yang dirasakannya, melihat dunia sama seperti yang mereka lihat. Hal itu dapat dilakukan dengan cara, antara lain, memerhatikan pesan dari sudut pandang pembicara, terlibat dalam pembicaraan dua arah, mencari pemahaman pemikiran dan perasaan bersama. Berdasarkan uraian tersebut jelaslah pendengar yang baik menjadi salah satu aspek pendukungan dalam memperoleh kesepakatan bersama.

Para negosiator sebelum menjalin kerjasama seperti dijelaskan Fisher, et al. (2000:43), dapat dimulai dari "mengenal pihak lawan secara pribadi sangat membantu dalam berunding. Saat yang baik untuk menjalin hubungan adalah pada saat perundingan belum berlangsung. Berusahalah menemuinya secara informal dan usahakan diri Anda untuk datang lebih awal, supaya tersedia banyak waktu untuk saling mengenal."
Temuan penelitian tentang hubungan baik diperoleh dari kerjasama yang memuaskan kedua belah pihak. Berdasarkan pengalaman informan, dimulai dari mengenal pihak lawan secara pribadi. Saat yang baik untuk menjalin hubungan adalah pada saat perundingan belum berlangsung. Berusaha untuk mengenal pihak lain lebih dekat dan mengetahui lebih jauh apa yang disukainya. Berusaha menemuinya secara informal dan usahakan untuk datang lebih awal, supaya tersedia banyak waktu untuk saling mengenal.

Temuan tersebut sejalan dengan pendapat DeVito (2013: 25), "Hubungan berlangsung di antara orang-orang yang berkomunikasi, melalui pemindahan pesan tertentu." Menurut Urban (227: xiv-xv), pilihan kata (diksi) dalam pesan verbal memiliki peran penting untuk mencapai keberhasilan negosiasi. Kata-kata yang digunakannya jumlahnya banyak sekali. seseorang sering tidak menyadari efek dari kata-kata yang digunakannya, kata-kata tersebut berdampak baik kepada orang lain maupun diri sendiri.

Untuk menilai kemampuan negosiasi seseorang ditunjukkan oleh respons yang diperoleh berupa pengertian dari diri sendiri maupun orang lain, sesuai pandangan Oswald (2009: xvi), "Kesuksesan hidup seseorang dimulai dari kemampuan membuat diri sendiri mengerti." Karena itu, untuk memeroleh kesepakatan, negosiator perlu mengubah pola pikir dan bahasanya yang diterapkan pada percakapan internal dan eksternal melalui latihan mengganti kata negatif dengan kata positif, melalui pengungkapan realitas mesti secara positif. Karena sesuai dengan karakteristik pikiran bawah sadar, bila seseorang menggunakan kata-kata negatif, ia akan menerima dan mewujudkan perasaan utama pikiran negatif tersebut" (Ratnasari, Mimbar Vol. XXVI No.2, Desember 2010).

Hasil penelitian Ashley D. Brown dan Jared R. Curhan yang dimuat pada Jurnal Psychological Science tentang "Pengaruh Gairah Fisiologis terhadap Hasil Negosiasi" menunjukkan bahwa gairah berefek menguntungkan pada hasil negosiasi pada peserta yang memiliki sikap positif terhadap negosiasi sebelumnya. sebaliknya, gairah berefek merugikan pada hasil negosiasi pada peserta yang memiliki sikap negatif terhadap negosiasi yang sebelumnya pernah dilakukan"(dalam pss.sagepub.com, 10 November 2013).

Temuan penelitian tentang upaya 
informan memelihara hubungan jangka panjang, informan sering bekerjasama dengan mitra bisnisnya, penawarannya tidak tinggi, melainkan dengan harga wajar." Karena itu, di antara kami sudah terbentuk pengertian, kepercayaan, setiap pihak memahami posisinya, masing-masing sebagai partner yang sungguh-sungguh dapat dipercaya dan kerjasama mereka merupakan sesuatu yang sangat menguntungkan.

Hal itu sesuai dengan penelitian Hamdan, dkk. (Mimbar Vol. 29, no 2. Tahun 2013), bahwa negosiasi bisnis untuk membangun kerjasama melalui tahap eksplorasi, penawaran, tawar-menawar, penyelesaian, dan pengesahan. Bekerjasama dengan pihak lain menggunakan pesan verbal secara jelas, singkat, dan bermakna positif, sedangkan pada nonverbal memerhatikan isyarat mimik muka, kontak mata, gerakan tangan, dan penggunakan busana yang sesuai.

Membina hubungan baik yang dilakukan informan, misalnya pada kesempatan berkumpul bersama temanteman atau keluarga menjadi sarana untuk melatih hubungan baik. Informan juga menghindari topik pembicaraan yang kurang menyenangkan bagi pihak lain. Selain itu, informan juga memikirkan terlebih dahulu apa yang hendak diucapkan. Kegiatan lainnya yang dilakukan informan dalam menjaga hubungan baik adalah dengan menjadi partner yang memberikan solusisolusi terbaik yang mendukung kesuksesan negosiator lain. Sesungguhnya negosiator lain adalah pribadi-pribadi yang ingin diperlakukan sebaik-baiknya. Kecepatan dan kualitas harus tinggi, tetapi melayani dengan hati adalah kewajiban.

Karena itu, menurut pendapat informan menjaga keakraban dengan negosiator lain merupakan hal yang tidak bisa ditawar. Apa yang diinginkan, dibutuhkan, dan diharapkan pihak lain tidak serta merta dipahami bila kita tidak menjalin keakraban. Karena hubungan dengan negosiator lain yang akrab, kemampuan mendengarkan pihak lain, akan menghasilkan nilai tambah, dibarengi dengan belajar dan memperbarui diri dari waktu ke waktu. Menurut Jackman (2004:95), kegiatan itu menjadi inti dari negosiasi, yaitu menemukan kesamaan antara hasil yang Anda inginkan dengan hasil yang diinginkan lawan negosiasi. Tahap ini adalah tahap di mana kedua belah pihak akan menghasilkan keuntungan bersama.

Bagi negosiator yang sering bekerja sama, Thomas ( 2007:76) berpendapat, "Semakin lama dan dekat hubungan Anda, semakin tidak pantas bagi Anda untuk memulai dengan penawaran tinggi. Seiring waktu, muncullah kepercayaan, dan kepercayaan menggantikan negosiasi. Karena dalam

Tabel 1

Kemampuan Negosiasi Pengusaha dalam Meningkatkan Kesepakatan Bisnis

\begin{tabular}{|c|c|c|}
\hline No & Kemampuan Negosiasi & Uraian \\
\hline 1 & $\begin{array}{l}\text { Berani menggali lebih banyak } \\
\text { informasi. }\end{array}$ & $\begin{array}{l}\text { a. Mengajukan banyak pertanyaan. } \\
\text { b. Memberi kesempatan kepada pihak lain untuk } \\
\text { bertanya. } \\
\text { c. Mempertimbangkan aspek perasaan lawan negosiasi } \\
\text { agar nyaman berkomunikasi dengan negosiator. }\end{array}$ \\
\hline 2 & $\begin{array}{l}\text { Sabar bertahan lebih lama dari } \\
\text { negosiator lawan. }\end{array}$ & $\begin{array}{l}\text { a. Negosiator menyediakan waktu untuk bertahan saat } \\
\text { negosiasi. } \\
\text { b. Negosiator berusaha mencurahkan pikiran positif yang } \\
\text { mendukung jalannya negosiasi. } \\
\text { c. Negosiator menyediakan tenaga mendukung jalannya } \\
\text { negosiasi. }\end{array}$ \\
\hline 3 & Berani meminta lebih banyak & $\begin{array}{l}\text { a. Fokus pada tujuan yang ingin dicapai. } \\
\text { b. Membuat urutan proses pencapaian. }\end{array}$ \\
\hline 4 & $\begin{array}{l}\text { Integritas menekan solusi menang- } \\
\text { menang. }\end{array}$ & $\begin{array}{l}\text { c. Memegang komitmen bersama secara konsisten. } \\
\text { d. Memerhatikan kepentingan bersama. }\end{array}$ \\
\hline 5 & $\begin{array}{l}\text { Bersedia menjadi pendengar yang } \\
\text { baik. }\end{array}$ & $\begin{array}{l}\text { a. Menyediakan waktu untuk diskusi sesuai topik } \\
\text { negosiasi. } \\
\text { b. Mendengarkan dengan saksama penjelasan pihak lain. } \\
\text { c. Menjadi pendengar yang empatik. }\end{array}$ \\
\hline
\end{tabular}

Sumber : Data Penelitian 
negosiasi yang ke sekian kalinya antara pihak-pihak yang sama dengan masalah yang sama, posisi pembuka akan berubah hampir menyerupai taraf kebersamaan, kepercayaan membuat negosiasi hampir tidak diperlukan lagi. Proses selanjutnya, di antara mereka terbentuk pengertian, di mana setiap pihak memahami posisinya; karena itu, di antara mereka terbentuk kepercayaan bahwa masing-masing sebagai partner yang sungguh-sungguh dapat dipercaya dan kerjasama mereka merupakan sesuatu yang sangat menguntungkan. Hal itu sesuai dengan pendapat Barron \& Kaus (2007: 58), jika negosiator ingin memengaruhi calon klien, mulailah merasakan pernyataan hubungan yang mendalam dengan calon klien tersebut, yaitu dengan menciptakan hubungan yang erat.

Pendapat yang hampir sama dikemukakan Hans-George Wolff dan Klaus Moser dalam Effect of Networking on Carier Succes: a Longitudinal Study (2000) bahwa jejaring sangat berkorelasi dengan kesuksesan karier, baik kesuksesan objektif atau subjektif. Objektif dalam artian yang tampak (kekayaan, misalnya), sedangkan subjektif lebih mengacu pada pengakuan orang lain (dalam Intisari, No. 620, 14 Mei 2014).

Salah satu perusahaan yang turut membesarkan bisnis kliennya berkat menjalin hubungan baik di antaranya Dwi Sapta, perusahaan yang bergerak dalam Adversiting Agency. Menurut Watono \& Watono (2011:42), "Dwi Sapta bukan hanya agency yang mengerjakan pesanan pekerjaan, tetapi sekaligus menjadi mitra klien dalam menghasilkan iklan-iklan yang berkualitas: turut mendorong penjualan produk-produk dengan kualitas image iklan yang tinggi." Berdasarkan uraian terdahulu, dapat diringkaskan temuan penelitian yang merupakan keunikan yang didapat dari para wanita pengusaha disajikan dalam Tabel 1 berikut.

Penjelasan pada Tabel 1 memerlihatkan temuan penelitian tentang kemampuan negosiasi pengusaha dalam meningkatkan kesepakatan bisnis. Kelima karakteristik personal tersebut penting kedudukannya dalam membekali pengusaha menjadi negosiator bisnis yang berhasil.

\section{Simpulan dan Saran}

Simpulan yang dapat dikemukakan, pengusaha memiliki kemampuan negosiasi yang baik; mereka memiliki keberanian menggali lebih banyak informasi dengan cara mengajukan banyak pertanyaan, memberi kesempatan kepada pihak lain untuk bertanya, mempertimbangkan perasaan lawan saat bernegosiasi. Pengusaha juga memiliki kesabaran untuk bertahan lebih lama dari negosiator lawan, dilakukan dengan menyediakan waktu lebih banyak, mencurahkan pikiran positif, dan menyediakan tenaga mendukung jalannya negosiasi. Selain itu, pengusaha juga memiliki keberanian meminta lebih banyak dengan membuat urutan proses pencapaian. Pengusaha juga memiliki integritas menekan solusi menang-menang dengan cara memegang komitmen bersama secara konsisten, dan memperhatikan kepentingan bersama. Di samping itu, pengusaha bersedia menjadi pendengar yang baik, dengan menyediakan waktu untuk diskusi, mendengarkan penjelasan pihak lain, dan menjadi pendengar yang empatik. Pengusaha dapat membina hubungan dengan mitra bisnisnya, hal itu berkaitan dengan keyakinan pihak lain pada kemampuan negosiator sebagai pihak yang dapat dipercaya.

Saran yang diajukan, pengusaha perlu meningkatkan keberanian menggali lebih banyak informasi dengan cara mempelajari pengetahuan teknis, didukung oleh keinginan yang kuat, dan ketajaman pikiran untuk mengkaji topik negosiasi, serta kemampuan memahami kondisi pihak lain. Kesabaran bertahan lebih lama dari negosiator lawan dapat ditingkatkan dengan cara negosiator melatih daya tahan, disiplin, mampu meyakinkan, dan menanamkan kepercayaan kepada pihak lain. Keberanian meminta lebih banyak dapat dipertahankan, antara lain, dengan mengasah kemampuan menyampaikan gagasan dengan lancar, runtut, dan jelas. Integritas solusi menangmenang penting diperhatikan pengusaha, karena kesepakatan tercapai bila para pihak memiliki komitmen memberi persetujuan dan merasa menang, menjadi pendengar empatik dan fokus pada topik negosiasi.

\section{Daftar Pustaka}

Barron, David R. \& Kaus, Danek S. (2007). The Power of Persuasion. Bandung: Momentum an Imprint of Salamadani.

Brown Ashley D. \& Curhan, Jared R. (2013). "The Polarizing Effect of Arousal on Negotiation". Jurnal Psychological Science. pss.sagepub.com, 10 November.

Budyatna, Muhammad dan Ganiem, 
Leila Mona. (2011). Teori Komunikasi Antarpribadi. Jakarta: Kencana Prenada Media Group.

Cohen, Steven.(2006). Negotiate This! (Bernegosiasi dengan Hati). Terj. Agus Maulana. Batam: Karisma Publishing Group.

Devito, Joseph A.,(2013). The Interpersonal Communication Book. Thirteenth Edition. Boston, Pearson International Editon.

Dawson, Roger. (2004). Secrets of Power Negotiating: Rahasia Sukses Seorang Negosiator Ulung. Terj. C. Louis Noviatno. Jakarta : PT. Gramedia Pustaka Utama.

Fisher R., Ury, W., Patton, B. (2000). Getting to Yes: Teknik Berunding Menuju Kesepakatan tanpa Kemaksakan kehendak. Jakarta: Yayasan Obor Indonesia.

Ikatan Wanita Pengusaha DPD Jawa Barat. iwapijawabarat.com. 23 Maret 2012.

Jackman, Ann. (2004). How to Negotiate: Teknik Sukses Bernegosiasi. Terj. Chefira Inda. Jakarta: Erlangga.

Hamdan, Y., Ratnasari, A., \& Hirzi, A.T. (2013). "Profil Negosiator Bisnis Wanita Pengusaha". Mimbar Vol. 29, No.2. pp. 235-245.

Koran-sindo.com. IWAPI Siap Cetak Pengusaha Tangguh. 6 Juni 2014.

Kotler. Philip. (2000). Marketing Management. New Jersey: Prentice Hall International, Inc.

Lewicki, Roy J., et.al. (2003). Negotiation. New York : The McGraw-Hill Co.Inc.

Mulyana, Deddy. (2000). IImu Komunikasi Suatu pengantar. Bandung: PT. Remaja Rosdakarya.

Oswald, Yvonne.(2009). Keajaiban Kata-Kata: Ubahlah Hidup Anda dengan Kata-Kata yang Positif. Jakarta:PT Gramedia Pustaka Utama.

Pikiran-rakyat.com. Masih Sedikit Wanita Jadi pengusaha. 8 Februari 2011.

Ratnasari, A. (2010). Pesan Positif dalam Komunikasi. Mimbar Vol. XXVI No.2. pp. 159-168.

Santosa, Awan. (2010). Psikologi Persuasi. Jakarta : PT Elex Media Komputindo,
Kelompok Gramedia.

Shimp.Terence. A. (2014). "Komunikasi Pemasaran Terpadu dala Periklanan dan Promosi". Terj. Harya BS, dkk. Jakarta: Salemba Empat.

Suaramerdeka.com. Pengusaha Perempuan Diharapkan Entaskan Kemiskinan. 6 Juni 2014.

Subianto, Basuki. (2004). Mengubah Tidak Mungkin menjadi Mungkin: Pengalaman Berbisnis dengan Sandaran Al Quran. Bandung: Al Bayan-Mizan.

Sujana, Asep ST. (2004). Retail Negotiator Guidance: Menyingkap Rahasia Sukses Global Retailer. Jakarta: PT. Gramedia Pustaka Utama.

Sutisna. (2001). Perilaku Konsumen dan Komunikasi Pemasaran, PT. Remaja Rosdakarya, Bandung.

Swa.co.id. Microsoft Indonesia. Kenalkan Komputasi Awan Ke Anggota IWAPI. 6 Juni 2014.

teraskreasi.com. Kowani Fair dan IWAPI Expo 2014. 6 Juni 2014.

Thomas Jim. (2007). Negotiate to Win : 21 Jurus Ampuh untuk Memenangkan Negosiasi. Jakarta : PT. Gramedia Pustaka Utama.

Urban, Hal. (2007). Positive Words, Powerful Results. Terj. Eta Sitepoe. Jakarta:PT Bhuana Ilmu Populer.

Watono, Aji \&Watono, Maya A. (2011). IMC That Sells. Jakarta : PT. Gramedia.

Wolff, Hans-George \& Moser, Klaus. (2000). Effect of Networking on Carier Succes : a Longitudinal Study Intisari, No. 620, 14 Mei 2014.

Wood, Julia T.(2013). Komunikasi Interpersonal: Interaksi Keseharian, Jakarta: Penerbit Salemba Humanika.

Yin, Robert K. (2002). Studi Kasus :Desain dan Metode. Jakarta : PT. RajaGrafindo Persada.

Ziglar, Zig. (2009). Ziglar on Selling : Pedoman Lengkap bagi Professional Penjualan. Jakarta: PT. Bhuana Ilmu Populer, kelompok Gramedia. 